\title{
Hemmansägare på övertid
}

Denna studie har sträckt sig från cirka 1870 och fram till 1900-talets slut, en lång tidsperiod präglad av enorma samhällsförändringar. Vid periodens inledning var Sverige fortfarande i huvudsak ett agrarsamhälle, där de flesta människor bodde på landsbygden och jordbruket utgjorde den viktigaste näringen. Vid 1900-talets slut levde över 80 procent av Sveriges befolkning i tätorter och andelen sysselsatta i jordbruket uppgick till 2 procent. ${ }^{592}$ Jordbruket gick från att vara självklar modernäring till att föra en undanskymd tillvaro. Trots förändringarna fanns bestående drag. Under hela perioden dominerades det svenska jordbruket av små och medelstora familjejordbruk. ${ }^{593}$ Parallellt med att de renodlade familjejordbruken etablerades i slutet av 1800-talet uppstod emellertid också andra brukarformer. Denna bok har handlat om en sådan: syskon som bott och drivit jordbruk tillsammans.

Medan familjejordbrukets bas var en kärnfamilj var syskonjordbrukets en relation mellan två eller flera syskon. Med utgångspunkt i familjehistorisk forskning konstaterade jag inledningsvis att sådana horisontellt utvidgade hushåll historiskt sett varit mycket sällsynta, åtminstone i Västeuropa. Ett antal observationer i tidigare forskning antydde dock att syskonhushåll blev vanligare på flera håll i Europa decennierna runt sekelskiftet 1900. Syftet med studien var därför att utifrån svenska förhållanden belysa syskonjordbrukets utveckling och förklara varför de uppkom. Undersökningen bestod av fyra delstudier, vilka redovisats i var sitt kapitel.

På ett övergripande plan understryker resultaten vikten av att problematisera familjens sammansättning och funktion i olika historiska kontexter, och de har också betydelse för hur sambandet mellan familjeform och modernisering bör förstås. ${ }^{594}$ Tidigare 
forskning har betonat att kärnfamiljen blev vanligare på bekostnad av vad som uppfattats som mer traditionellt utvidgade familjeformer, men det finns variationer i mönstret. Som framgått av undersökningen uppkom ett stort antal bondehushåll vars främsta kännetecken var att de var utvidgade i sidled. Det kan vid första anblicken se ut som en traditionell familjeform men är i själva verket en modern företeelse.

\section{Omfattning och särdrag - en företeelse eller flera?}

Den kronologi som jag skisserade med ledning av tidigare forskning bekräftades i allt väsentligt i de fyra delstudierna. År 1870, det första undersökningsåret för hushållsanalysen i kapitel 4, kunde enbart en handfull syskonenheter identifieras. De utgjorde inte mer än en procent av bondehushållen, och allting tyder på att de fram till 1800-talets slut var sällsynta undantag. Under seklets sista decennier inträffade dock avgörande förändringar. Fram till 1890 års tvärsnitt ökade andelen syskonjordbruk till fyra procent. Det är ingen anmärkningsvärt stor andel, men det var en avsevärd ökning på bara tjugo år. Under samma tid reformerades egendomsrätten. Genom en serie politiska beslut förändrades på några decennier de grundläggande principerna för jordägandets reproduktion. Följden blev att generationsväxlingens viktigaste moment - sammanföringen av arvslotter genom en inlösenprocess - avreglerades. Vem som skulle lösa in vem blev en intern angelägenhet inom familjen. Den ökade friheten anses ofta ha underlättat egendomens rörlighet och var ett steg mot en friare jordmarknad. ${ }^{595}$ Det var dock inte en ensartad utveckling. Parallellt tycks reformerna ha banat väg för mer trögrörliga ägandeförhållanden där samägande mellan arvingar blev en bestående egendomsstruktur. Indikationer på de förändrade egendomsförhållandena fanns redan vid sekelskiftet: en viktig bakgrund till samägandelagen var just erfarenheter från situationer när arvingar samägt egendom.

Om fröna till syskonjordbruken kan spåras till decennierna före sekelskiftet, var 1900-talets första hälft otvetydigt deras blomstringstid. Hushållsanalysen talar sitt tydliga språk: andelen syskonhushåll 
dubblerades först mellan 1890 och 1910 och därefter ytterligare en gång fram till 1930. Från att ha varit undantagsfall blev syskonjordbruken snabbt ett vanligt inslag på svensk landsbygd. Toppnoteringen tycks ha nåtts på 1930-talet, då de utgjorde vart sjätte jordbruk. I hälften av de studerade socknarna var andelen ännu större. Syskongårdar var ett resultat av en generationsväxling, och av de jordbruk som gick i arv kan uppemot vart femte ha resulterat i att flera syskon blev kvar på gården. Efter 1930-talet övergick ökningen i en relativt lång stabil fas, då andelen syskonjordbruk utgjorde strax över tio procent av bondehushållen.

Ökningen fram till 1930-talet kan beläggas i nästan alla undersökta socknar och de beskrivningar av arvssedvänjor i olika landsändar som analyserades i kapitel 3 visade på samma utveckling. Tre nationella enkäter från 1907, 1919 och 1935 visade att generationsväxlingar med tiden oftare slutade med att flera arvingar bodde kvar tillsammans på gårdarna, och arrangemanget blev inte sällan varaktigt. Mönstret fanns i hela landet, men hur vanliga syskonjordbruken var varierade. Bland de tio socknarna fanns de där syskonhushållen inte nådde tio procent, men också de där de utgjorde mer än vart tredje bondehushåll. På ett övergripande plan tycks de ha varit något vanligare i västra Sverige, särskilt efter 1930. De regionala skillnaderna är dock osäkra och utgör mer en utgångspunkt för vidare forskning än ett slutgiltigt resultat. Ett mer genomgående kännetecken var arvingarnas civilstånd. Enkätmaterialet visade tydligt att syskonens gemensamma övertagande av gården och deras civilstånd som ogifta ofta nämndes i samma andetag. Mönstret bekräftades av hushållsanalysen. Även om det fanns syskonhushåll med ett gift syskon kännetecknades de flesta av att arvingarna förblev ogifta.

Enkätsvaren visade att samboende syskon inte var något okänt fenomen, men det var först i samband med omläggningen av den svenska jordbrukspolitiken i mitten av 1900-talet som syskonenheterna började uppmärksammas. När rationaliseringen av jordbruksstrukturen tog fart under 1950-talet inringades snabbt ett problem: samägda jordbruksfastigheter. Under de följande decennierna framställdes de som bekymmersamma i flera avseenden 
och i slutet av 1980-talet infördes lagstiftning för att bland annat minska dödsbons jordinnehav. Vilka ägandesituationer som dolde sig bakom de många samägda gårdarna ägnades emellertid begränsat intresse. Under 1950-talet tycks det i stor utsträckning ha varit syskonjordbruk, men bilden förändrades över tid. Hushållsanalysen visade att syskonenheternas andel successivt minskade, särskilt efter 1970. Det sista undersökningsåret, 1991, var den nere i 6 procent. Den betydelse syskongårdarna uppnått under 1900-talets första hälft försvann således under den andra. Att samägda jordbruk fortsatt utgjorde en betydande del av landsbygdens fastighetsbestånd berodde på att andra samägandesituationer - exempelvis syskon som behöll äganderätten men flyttade eller arrenderade ut jordbruket - blev vanligare.

Ungefär samtidigt som syskonjordbruken började tappa i betydelse förändrades deras särdrag. I kapitel 4 identifierade jag 259 syskongrupper vilka delades in i tre grupper utifrån när de först dök upp i materialet: 1870-1910, 1930-1945 eller 1971-1991. Mellan de två första grupperna var skillnaderna mycket små. De sammanboende syskonens antal varierade mellan två och sex, bröder var något vanligare men systrar fanns på de flesta enheter, syskonens genomsnittsålder var nära eller några år under den genomsnittlige jordbrukarens och på nästan varannan gård fanns en förälder kvar i hushållet. På de syskonjordbruk som etablerades efter seklets mitt hade dock oftast både föräldrar och systrar försvunnit och kvar fanns två bröder. I takt med att syskongårdarna blev färre började arvingarnas snittålder stiga, och på 1990-talet var de kvarvarandes ålder i genomsnitt närmare 65 år. Något tillspetsat kan själva företeelsen syskonjordbruk sägas ha varit pensionsfärdig.

I kapitel 4 undersökte jag syskonjordbrukens storlek och grad av rationalisering. År 1945 fanns det både stora och små syskonjordbruk och de var inte tekniskt eftersatta - mekaniseringsgraden varierade med jordbrukets storlek och syskongårdarna skilde inte ut sig från andra jordbruk. Ett tydligt drag var att syskonhushållen var vanligare på större gårdar, särskilt gårdar med mer än 20 hektar åker. Under seklets andra hälft förändrades bilden, och de syskonjordbruk som återstod 1991 var i stor utsträckning småbruk under 
tio hektar. Att döma av situationen på de jordbruk som intervjuerna i kapitel 5 behandlade låg de sällan i framkant för efterkrigstidens rationalisering och mekanisering.

Det finns alltså flera skäl att skilja mellan syskonhushåll som etablerades före respektive efter cirka 1950. De förstnämnda uppvisade en stor spridning i antalet syskon och var vanligast på stora gårdar, däremot var syskonens ålder och jordbrukets mekaniseringsgrad i paritet med andra samtida jordbruk. Längre fram blev syskonjordbruk mer synonymt med två äldre bröder som likt Erik och Sigvard drev ett småbruk med äldre metoder.

Ett utmärkande drag var dock bestående: få syskon ingick äktenskap. Av de samboende syskonen i hushållsanalysen var nära 85 procent ogifta, vilket innebar att det bara fanns ett äkta par på runt var tredje enhet. De olika delstudierna visade att äktenskap och syskonskap var tätt sammanlänkade. Det stora flertalet giftermål ingicks på enkönade enheter, vilket ur ett hushållsperspektiv innebar att äktenskap fick en kompletterande funktion. Det är emellertid i sig inte uppseendeväckande. När en arvinge ensam övertog en gård och gifte sig blev effekten densamma: gårdens hushåll kom att bestå av både män och kvinnor. Det påfallande med syskonjordbruk är att äktenskap var betydligt ovanligare på gårdar där det fanns både bröder och systrar. Som framgick av bland annat intervjuundersökningen tycks det inte sällan ha varit svårt att inom samma hushåll kombinera syskonrelationen med ett äktenskap. Längre fram i kapitlet diskuterar jag äktenskapsförhållandena mer ingående.

\section{Syskonhushållets funktion}

Hur syskonjordbruken har fungerat belyste jag främst i kapitel 4 och 5. Den kanske viktigaste slutsatsen var att syskongårdar inte på något avgörande sätt tycks ha skilt sig från vanliga familjejordbruk. Arbetsuppgifterna fördelades i stor utsträckning i enlighet med samtida genusarbetsdelning. Det var brukligt att bröder hade huvudansvaret för utearbete och maskiner, systrar för hushållsarbetet. Mjölkhanteringen, som oftast utgjorde jordbrukets ekonomiska stomme, sköttes vanligen av kvinnor, men fanns en mjölkmaskin 
kunde arbetet också utföras av män. På nära nog alla de enheter som intervjuerna rörde fanns det en arbetsledande position - alltid en man - och en position som ansvarig för hushållet - nästan alltid en kvinna. I många fall intog syskonen samma positioner som om de hade varit ett gift par.

Av intervjuerna i kapitel 5 framgick att syskonen ofta hade en mycket rigid arbetsdelning sinsemellan. Var och en blev specialist på sina sysslor, men hushållet var sårbart om någon föll ifrån. När sådana krislägen inträffade tycks dock problemen ha kunnat lösas, bland annat genom att syskon flyttade hem igen. I flera fall går det att skönja en ordning där särskilt systrar formellt lämnade hushållet men i praktiken behöll ett ansvar och utförde arbete på gården. Utflyttade bröder kunde också återkomma under sommarmånaderna för att tillgodose behovet av extra arbetskraft under högsäsongen. Sådana lösningar innebar att hushållets gränser kunde vara flytande, och en analys av boendeformerna förmår inte täcka in mångfalden av arbetsuppgifter och av relationer mellan syskonen.

En analys av hushållets funktion får inte överskugga att det fanns tydliga maktrelationer inom dess ramar. Syskonen var långtifrån alltid jämbördiga och det var framför allt kvinnor som befann sig i underläge. Det var inte ovanligt att en systers ställning mer liknade en hushållerskas. De olika positionerna och maktförhållandena i hushållet tycks i betydande utsträckning ha varit avhängiga ägandeförhållandena. På många enheter hade de boende en gemensam hushållskassa och var således också ekonomiskt ett kollektiv. Ekonomin berodde dock på ägandeförhållandena. Många gårdar ägdes gemensamt av syskonen, men det var minst lika vanligt att hela fastigheten ägdes av en bror, i vissa fall av två bröder gemensamt. I sådana fall begränsades gårdsekonomin till delägarna, vilket innebar att det nästan alltid var systrar som stod utanför den ekonomiska gemenskapen. En sådan position kunde vara mycket sårbar. Utan del i fastigheten var de i princip anställd arbetskraft, men inte sällan utan lön. Förutom att de hade ett begränsat handlingsutrymme uppstod i det långa loppet betydande risker, exempelvis fick de en mycket låg pension. 


\section{Syskonjordbruk som organisationsstruktur}

Undersökningens resultat kan knytas till den diskussion som Robert A. Pollak fört om familjejordbrukets organisatoriska fördelar. Enligt honom har familjebaserad jordbruksproduktion tydliga organisationsfördelar: billig arbetskraft, god kännedom om arbetets förutsättningar (och därmed mindre behov av arbetsledning) samt stark lojalitet med produktionsenheten. Finns dessutom en möjlighet att senare förvärva gården är arvingen sannolikt väl motiverad att arbeta hårt. ${ }^{596}$ Liam Kennedy betraktar på liknande sätt generationsväxlingen som en bytesprocess mellan arvlåtare och arvinge. De förstnämnda kan inte konsumera obegränsat (då dräneras gården på resurser), men genom att utse en arvinge säkerställer de sin tillgång till arbetskraft samt framtida social omsorg och bibehållen status. Arvingen måste i sin tur acceptera en tid som underordnad, och sannolikt underbetald, arbetskraft och eventuellt även skjuta på äktenskap och familjebildning, men i gengäld vinner han på sikt rätten till egendomen. Utbytet är långsiktigt och fyllt av stora och små fallgropar, men Kennedy understryker att familjen utgör "a particularly good organizational structure for handling complicated, long-term exchanges". ${ }^{597}$ På liknande sätt framhåller Pollak det familjebaserade jordbrukets goda förutsättningar att övervaka och leda arbetskraft som kännetecknas av att de vanligen inte befinner sig på samma fysiska plats. ${ }^{598}$ De organisatoriska fördelarna ligger dels i starkare personliga band mellan hushållets medlemmar och en form av familjemoral, dels i att familjen erbjuder en social trygghet, särskilt på ålderdomen. Så länge gården förmår försörja familjen har således dess medlemmar en mycket stark drivkraft att arbeta och hålla den i stånd. ${ }^{599}$

Pollak och Kennedy utgår från ett klassiskt familjejordbruk där en arvinge övertar gården, men resonemanget kan lätt överföras på syskonjordbruk. På några punkter innebar de senare snarast att de organisatoriska fördelarna förstärktes. Arbetsstyrkan var billig, lojal och bunden till gården, och dessutom sedan barnsben väl införstådd med gårdens förutsättningar. Eftersom syskonen som regel hade vuxit upp på gården, som inte sällan varit i släkten flera generationer, kände de sannolikt mer solidaritet än vad 
som var fallet på ett familjejordbruk där ena makan var ingift. Hushållsmedlemmarna kände varandra utan och innan och deras lojalitet gällde såväl varandra som omsorgen om åldrande föräldrar. Pliktkänslan bör ha förstärkt familjesammanhållningen. ${ }^{600}$ Om alla var delägare i fastigheten gynnade det delaktigheten och motivationen ytterligare. Eftersom syskonen var i ungefär samma ålder hade de en gemensam anledning att på sikt trygga sin sociala säkerhet. Betraktat som organisatorisk lösning för arbetskraft och social trygghet hade syskonjordbruket således påtagliga fördelar. Transaktionskostnaderna var, åtminstone på pappret, minimala. En nackdel var dock gårdens framtidsperspektiv. Saknades en given efterträdare fanns en påtaglig risk för att motivationen med tiden kunde sjunka.

Syskonjordbruk kan således ses som en organisationsstruktur för att tillgodose behov av arbetskraft och lösa frågor om social trygghet. Långtifrån alla jordbruk blev dock syskongårdar. De strukturella förutsättningarna satte ramarna för hur människor handlat, men givet dessa fanns olika handlingsalternativ. I kapitel 1 ställde jag frågan huruvida syskonjordbruken uppkom som ett resultat av ett antal icke-händelser utan avsikt att syskonen skulle överta gården, eller om de snarast bör ses som en medveten strategi. Delstudierna har blottlagt spänningar både mellan arvingarna och mellan generationerna. Flera informanter talade om konflikter mellan syskonen - och intervjumaterialet som helhet ger troligen en något för ljus bild av förhållandena. Det var dessutom långtifrån alltid som alla stannade på gården. Att arvingar flyttade från gården kunde leda till konflikter med de syskon som stannade. Detta kan tolkas som ett slags motsättning mellan individuella och mer kollektiva strategier. Den som flyttade satte sina egna mål framför gårdens och kunde anses ha svikit solidariteten.

Vem eller vilka som definierade familjestrategierna är emellertid en svår fråga. Någon skarp styrning från föräldrarnas sida är svår att belägga. Föräldrar kunde sätta sig emot äktenskapsplaner, men $\mathrm{i}$ intervjumaterialet förekommer bara några enstaka fall då föräldrarna aktivt styrde barnen till att bli kvar. Det troliga är att valet att stanna var individens, vilket inte hindrar att det gjordes 
med hänsyn till övriga familjemedlemmar. Någon skarp åtskillnad mellan individuella och familjebaserade strategier är därför svår att upprätthålla. Enligt min mening är det rimligare att betrakta syskonjordbruken som ett uttryck för kollektivism och underordnande av individen, än tvärtom. Det innebär inte att syskonhushållet genomgående präglades av endräkt. Spänningarna inom syskonhushållet ömsom förde syskonen samman, ömsom splittrade dem. Laurence Fontaine och Jürgen Schlumbohm framhåller att även om hushållet framträdde som en kollektivt handlande enhet var det ett centrum för både centrifugala och centripetala krafter. ${ }^{601} \mathrm{Om}$ medlemmarnas arbetskraft var av central betydelse för jordbruket kunde situationen bli svårbemästrad när någon flyttade. Över tid förändrades emellertid de strukturella förutsättningarna, vilket möjliggjorde förändrade strategier. Gårdsbruket kanske lades ner eller arrenderades ut, men samägandet kunde bestå. Social omsorg kunde tillgodoses på andra sätt samtidigt som nya arbetsmarknader öppnade möjligheter för andra livsval.

En diskussion om familjer och individer kan ge intrycket att alla arvingarna hade en likvärdig position. Så var dock inte fallet. Det fanns klara könsskillnader, och systrar hade ofta hade en sämre position. Även om syskon övertog en gård tillsammans skilde sig deras villkor och många kvinnor tycks ha blivit kvar för att ta hand om sina bröders hushåll. Någon kvinnlig emancipation rörde det sig knappast om.

\section{Fem delförklaringar}

Hur bör syskonjordbrukens uppkomst förklaras? Varför växte ett stort antal bondehushåll med sammanboende syskon fram på den svenska landsbygden runt förrförra sekelskiftet? Det är svårt att peka på en enskild omständighet som avgörande. Syskonenheternas omfattning, utbredning och föränderlighet tyder på att svaret måste sökas i ett flertal samverkande faktorer. I delstudierna har olika aspekter av syskonjordbrukens bakgrund belysts och nu vill jag fläta ihop dessa trådar.

För det första finns en rättslig och politisk förklaring. Förändringar 
i egendomsrätten under 1800-talets slut skapade nya handlingsalternativ för arvingarna: istället för att bli inlösta kunde de behålla sin andel i gården. Vilken roll denna förändring spelade är svårt att säga, men uppenbart är att samägandet ökade. Ett sätt att undvika samägandet var att föräldrarna i förtid sålde gården till en arvinge. Som framgick av intervjuerna var detta dock ovanligt på syskonjordbruken. Även om ägandeförhållandena senare kunde ändras inträdde de flesta syskongårdar i en samägandesituation eftersom successionen inte ordnats innan en förälder avled. Den enskilda arvinge som därmed blev delägare kunde välja mellan att sälja sin lott till ett eller flera syskon, behålla den eller försöka bryta ut och sälja den på marknaden. Det sistnämnda alternativet var både omständligt och kostsamt och riskerade att leda till en konflikt med övriga syskon. Att denna möjlighet fanns kan ändå ha haft betydelse, eftersom den i teorin gav varje arvinge en starkare position.

Som delägare hade arvingarna vetorätt när det gällde fastighetens förvaltning. De rättsliga förändringarna i egendomsrätten understöddes av den förda jordbrukspolitiken. För att genomföra strukturrationaliseringen gjordes omfattande statliga ingrepp men trots att samägda fastigheter tidigt identifierades som ett problem dröjde åtgärderna. Statsmakternas hållning präglades länge av en ovilja att intervenera i ägandeförhållandena. Samägandet fick bestå, likaså det vidsträckta släktundantaget $\mathrm{i}$ jordförvärvslagstiftningen. Det var först mot slutet av 1970-talet som regelverket förändrades, och då hade syskonjordbruken redan börjat bli färre.

För det andra spelade de ekonomiska förutsättningarna stor roll. Svårigheter att uppbåda kapital för att lösa in medarvingar kan förklara samägandet, men inte att syskonen fortsatte bo ihop. Den förklaringen är mer passande för de samägandeformer som uppkom senare under 1900-talet: arvingar som fortsatte äga gården ihop men inte bodde tillsammans. En viktigare ekonomisk förklaring var arbetskraftsbehovet. Den indelning i storlekskategorier som gjordes i kapitel 4 visade att antalet syskon ökade med storleken på jordbruket. Eftersom större jordbruk krävde mer arbete är det rimligt att tolka detta som ett sätt att möta arbetskraftsbehovet. 
Slutligen visade intervjuerna i kapitel 5 att så gott som alla syskon på gårdarna var direkt involverade i driften. Föll någon av dem bort behövde de ersättas, vilket visar att det arbete de utförde var mer eller mindre nödvändigt för gårdens fortlevnad. Även om det $i$ enstaka fall förekom anställd arbetskraft så utgjorde syskonen utan tvekan den centrala arbetsstyrkan på gårdarna. Därigenom blev det sannolikt svårare att bryta upp från föräldrahemmet.

Det är välkänt att det från 180o-talets slut blev allt svårare att hålla kvar arbetskraft inom jordbruket när industrin lockade med högre löner. ${ }^{602}$ Behovet av mänsklig arbetskraft var dock fortsatt stort; det var först på 1940-talet som traktoriseringen tog fart och maskiner på bred front ersatte människor. ${ }^{603} \mathrm{På}$ de flesta gårdar fick familjemedlemmar ta över allt mer av det nödvändiga arbetet. En möjlig tolkning är således att syskonhushållen var en lösning på jordbrukets arbetskraftsbehov. Ett syskon fick ersätta en anställd dräng, piga eller hushållerska. Detta har sannolikt störst förklaringsvärde för större jordbruk, där det fanns flera arbetande syskon. På dessa enheter försvann också viktiga arbetskraftsresurser utanför hushållets ram i och med att systemet med dagsverksskyldiga torpare successivt avvecklades fram till $1944 .{ }^{604}$ Men arbetskraftsbehovet var givetvis stort även på de mindre jordbruken. Ett mindre bärkraftigt småbruk kunde klara sig längre om det drevs av flera hårt arbetande syskon, särskilt om någon av dem hade inkomster utanför jordbruket. Slutligen kan syskonhushållet ha varit fördelaktigt för de enskilda arvingarna, inte bara för gården. Under tider med hög arbetslöshet kunde det te sig rationellt att arbeta kvar hemma, eller rentav återvända, för att bida sin tid i väntan på en ljusning på arbetsmarknaden. Att syskonjordbruken tycks ha varit som flest i samband med 1930-talskrisen, med dess omfattande arbetslöshet, stöder den tolkningen.

För det tredje spelade sociala förhållanden in. I sin undersökning av 1900-talets familjejordbruk visar Iréne Flygare att generationsväxlingar tenderade att ta allt längre tid, bland annat på grund av en ökad medellivslängd och en ovilja att överlåta ägandet i förtid. ${ }^{605}$ Samma tendens framträdde i enkätsvaren. Att föräldrarna åtminstone fram till 1900-talets mitt ofta utgjorde en del av syskonjordbruken 
framgick i både kapitel 4 och 5 . Även om jordbruksdriften övertagits av barnen förefaller många föräldrar ha behållit äganderätten livet ut. Det dominerande mönstret var att generationsväxlingen inte påbörjades förrän en av föräldrarna avled. En viktig faktor bakom många syskonjordbruks etablering tycks därför ha varit att föräldrarna inte drog sig tillbaka utan fortsatte spela en viktig roll både för hushållet och ägandeförhållandena. Det är troligt att det bakom många föräldrars ovilja mot att frånträda gården låg en oro för sin egen situation på ålderns höst. Äldreomsorgen befann sig i en brytningstid. Det traditionella systemet där gården överläts i utbyte mot undantagsförmåner var på tillbakagång, men välfärdsstatens äldrereformer låg ännu något decennium bort och den offentliga äldrevård som erbjöds bar ännu vid seklets början drag av fattigvård. ${ }^{606}$ Som en följd blev det, som Ulla Rosén visar i en studie av äldreomsorgens förändring, vanligare att de äldre bodde tillsammans med sina barn istället för i eget hushåll. ${ }^{607}$ Den sociala omsorgen om de äldre "familjiserades". På många syskonjordbruk var det med andra ord inte bara syskonen som lät bli att bryta upp från det gamla hemmet. Föräldrarna gjorde det inte heller.

För det fjärde har demografiska förhållanden ett visst förklaringsvärde. Richard Paping pekar på den stora folkökningen i Nederländerna som en bakgrund till uppkomsten av syskonenheter. Om målet var att så många arvingar som möjligt skulle bli jordbrukare räckte inte gårdarna till såvida inte syskon övertog dem ihop. ${ }^{608}$ I samband med diskussionen i kapitel 3 om de låga giftermålstalen i Sverige under det sena 1800 -talet pekade jag på att även den svenska utvecklingen rymmer en befolkningsförändring där höga döds- och födelsetal successivt ersattes av låga. Eftersom dödligheten sjönk först och nedgången i nativitet släpade efter blev konsekvensen, precis som i Nederländerna, en folkökning. I befolkningsstatistiken märks en kraftig stegring av antalet unga vuxna, särskilt under 1900-talets första decennier. ${ }^{609}$ Det måste dock påpekas att långtifrån alla dessa bodde på landsbygden och många unga valde också runt sekelskiftet att emigrera. Det var inte heller så att det vid alla arvskiften på bondgårdarna fanns sex-åtta arvingar; syskonjordbruk kunde uppstå även om det bara fanns 
två barn i familjen. På ett övergripande plan bör dock de större syskonskarorna ha inneburit en ökad press på att genomföra ett arvskifte som både skapade rättvisa mellan många syskon och tryggade gårdens fortlevnad som produktionsenhet. Det senare måste ses mot bakgrund av att utvecklingen mot ett mer animaliebaserat jordbruk medförde att byggnader blev mer värdefulla. Att uppföra nya ekonomibyggnader blev allt mer kostsamt och det blev därmed viktigare att hålla samman gården. ${ }^{610}$

För det femte ligger en del av förklaringen i kulturella aspekter. Utvecklingen mot att gårdar i större utsträckning drevs av familjemedlemmarna själva var även relaterad till det försvinnande drängoch pigsystemet i omvänd riktning. Tidigare hade det varit vanligt att barn till bönder tjänade som dräng eller piga några år innan de bildade familj. Gradvis under 1800-talet blev det istället regel att tjänstefolket hämtades från de obesuttna skikten och således hade en annan social bakgrund. ${ }^{611}$ Den sociala slutenheten innebar att bondbarnens alternativ begränsades, och såvida de inte emigrerade eller lämnade landsbygden blev de som unga vuxna i högre grad kvar i föräldrahemmet. Denna förändring satte avtryck i språket: orden "hemmadotter" och "hemmason", en ogift och något äldre kvinna eller man som utan att bedriva något egentligt yrke bodde kvar i föräldrahemmet, introducerades i det svenska språket just under 1800 -talets sista decennier. ${ }^{612}$

Istället för att arbeta åt andra markerade många jordbrukarfamiljer sin status som självständiga hemmansägare. Betydelsen av hemmet betonades också i det offentliga samtalet. Nils Edling framhåller föreställningen om det goda hemmet som "sekelskiftets samlande politiska metafor" och drar en tydlig linje från egnahems- till folkhemspolitiken. ${ }^{613}$ De kulturella aspekternas betydelse ligger i linje med de tankegångar Börje Hanssen torgfört. Han skisserar en utveckling där hemmansägarna i takt med den agrara revolutionens framsteg blev allt mer klassmedvetna. Det uppstod en sofistikerad "släktideologi" och familjerelationerna blev mer betydelsefulla. ${ }^{614}$ Ett tydligt uttryck för familjens stärkta ställning var en förändring i namnskicket. Seden att bilda efternamn efter faderns förnamn (patronymikon) avvecklades successivt under 1800-talets sista de- 
cennier till förmån för fasta släktnamn. ${ }^{615}$ Därigenom markerades en gemenskap inom familjen.

De fem delförklaringarna ovan kan även appliceras på frågan varför syskonjordbruk försvann. Den demografiska transitionen innebar att födelsetalen sjönk och syskonskarorna krympte. När den arbetsbesparande tekniken efter andra världskriget slog igenom på allvar minskade behovet av mänsklig arbetskraft och ett medelstort jordbruk kunde med ändamålsenliga maskiners hjälp drivas av en person. Som en konsekvens blev den ensamme manlige bonden, som var ett undantag före 1950, vanligare. ${ }^{616}$ Med äldreomsorgens utbyggnad och pensionssystemets utveckling uppenbarade sig andra alternativ för vård och trygghet. Gårdens betydelse som säkerhet på ålderns höst minskade. Det var fortsatt möjligt att samäga fastigheter, men jordbrukets försämrade ekonomiska ställning i kombination med politiska insatser för att främja en förflyttning av arbetskraft till industriella näringar gjorde andra alternativ än syskonjordbruk mer lockande. Samägandet bestod, men arvingarna flyttade. I skenet av samhällsomvandlingen förändrades även synen på bonden. Efterkrigstidens jordbrukare var knappast en statusmedveten landsbygdsaristokrati. Syskonjordbrukets korta storhetsperiod måste följaktligen förstås mot bakgrund av att de faktorer som banade väg för utvecklingen från slutet av 180o-talet minskade i betydelse under 1900-talets andra hälft.

De skisserade förklaringarna kan med andra ord bidra till att förklara varför syskonjordbruk som företeelse uppkom och så småningom upphörde, men vilket eller vilka skäl som övervägde i det enskilda fallet varierade naturligtvis. De fem delförklaringarna bör emellertid inte tillmätas samma tyngd. De rättsliga, demografiska, sociala och kulturella aspekterna var viktiga bakomliggande strukturer. De skapade förutsättningar som underlättade syskonjordbrukens framväxt, men de var inte direkt avgörande. Då hade den ekonomiska aspekten en mer definitiv inverkan. Syskonjordbruk var i likhet med familjejordbruk en rationell organisationsstruktur, präglad av mycket låga transaktionskostnader, och det är rimligt att se deras utveckling som en pendang till familjejordbrukets uppkomst i spåren av 1870-talets jordbrukskris. När de ekonomiska 
förutsättningarna förändrades anpassade sig jordbruket. I den anställda arbetsstyrkans ställe sattes familjemedlemmar och i samspel med de bakomliggande strukturerna skapades starka band av plikt, beroende och lojalitet - både mellan och inom generationerna. Den avgörande skillnaden var att familjejordbrukets nav var ett gift par, medan syskonjordbruket hade sitt centrum i själva syskonrelationen.

Detta resonemang leder vidare till det bestående kännetecknet för syskonjordbruken: de få äktenskapen. Vid sidan om de ovan berörda förklaringarna finns därför skäl att diskutera vilken roll äktenskapsförhållandena egentligen spelade.

\section{Istället för äktenskap}

I kapitel 3 påpekade jag att den sjunkande giftermålsfrekvensen under 1800-talet knappast kan förklaras demografiskt. Även om det lokalt kunde finnas skevheter fanns inte ett generellt underskott på ogifta kvinnor. Rimligare är att, som Maria Sjöberg, tolka de uteblivna äktenskapen som ett medvetet val. Sjöbergs argumentation går ut på att kvinnor avstod från att gifta sig på grund av äktenskapets föråldrade egendomsregler. ${ }^{617}$ Hon förutsätter dock att samlevnaden mellan män och kvinnor bestod, det var enbart äktenskapets rättsliga följder som undveks. Min undersökning har dock visat att även samlevnaden kunde utebli. Den stora andelen ogifta kan därför inte uteslutande förklaras som resultatet av en könslig kamp. Frågan är inte enbart varför äktenskap uteblev utan varför så många förblev singlar. Var det ett resultat av misslyckanden eller av ett medvetet och rationellt val?

Av genomgången av tidigare forskning i kapitel 1 framgick att syskonhushåll vid 1900-talets början även framträder i andra länder, däribland på Irland. Också där var giftermålsfrekvensen låg. Timothy Guinnane beräknar att på den irländska landsbygden var uppemot var färde person över 45 år ogift 1911. Det har, precis som för svenska förhållanden, traditionellt förklarats demografiskt och med utgångspunkt från män - det fanns inte tillräckligt med kvinnor för dem att gifta sig med, ett påstående som Guinnane avfärdar. 
Istället riktar han in sin diskussion på underliggande antaganden i John Hajnals teori om det västeuropeiska giftermålsmönstret och pekar på att den irländska empirin inte sammanfaller med teorins förutsägelser. Eftersom en grundsats i Hajnals teoribygge är att det krävdes ekonomiska resurser för att bilda ett hushåll borde, menar Guinnane, goda ekonomiska förhållanden leda till att fler gifte sig. Men trots att inkomsterna på Irland generellt steg från 1800-talets slut inträffade det motsatta: andelen ogifta ökade. Dessutom var det "fel" personer som förblev ogifta: andelen gifta hushållsföreståndare var lägre bland bönder än bland arbetare och sjönk med storleken på gården. ${ }^{618}$

Med utgångspunkt i dessa observationer poängterar Guinnane att Hajnals teori saknar en diskussion om vilka incitament som under olika tidsperioder och sociala sammanhang funnits för att gifta sig. ${ }^{619}$ Strävan att ingå äktenskap är ett axiom hos Hajnal, vilket medför att ingen egentligen bestämmer sig för att gifta sig, eller med Guinnanes ord: "they either do or do not achieve their marriage targets" ${ }^{620}$ Guinnane argumenterar istället för att de många uteblivna äktenskapen på den irländska landsbygden var resultat av medvetna val. I själva verket menar han att mönstret berodde på två olika val: personer hade varken gift sig eller, som så många irländare tidigare under 1800 -talet, emigrerat. När bönder valde att leva ogifta skapade de en potentiell position som "spouse substitutes" för bland annat syskon, och när de senare därigenom fann emigration mindre attraktivt "they made celibacy more viable for those who controlled farmsteads". ${ }^{621}$ För ett ogift syskon kunde det rentav vara fördelaktigt att stanna i hushållet även om brodern eller systern gifte sig, eftersom det innebar en säkerställd social och ekonomisk position som var klart bättre än vad som kunde förväntas på annat håll.

Grundantagandet i Guinnanes resonemang är att äktenskap inte var ett självklart mål utan byggde på en social och ekonomisk kalkyl. Kostnaderna för äktenskap och familjebildning var stora, och om det fanns andra sätt att uppnå vissa av de fördelar som äktenskap gav - arbetskraft, gemenskap, social omvård et cetera - kunde det under vissa förutsättningar framstå som ekonomiskt rationellt 
att inte gifta sig. ${ }^{622}$ Det var sådana förutsättningar som Guinnane menar uppstod på Irland runt sekelskiftet 1900 när emigrationens dragningskraft började klinga av samtidigt som de sociala och ekonomiska förhållandena stärktes. Skilda samhälleliga förändringar skapade för böndernas del ett alternativ till giftermål och barnalstring som inte sänkte deras samhälleliga status. Guinnane framhäver särskilt att sådana alternativ "took the form of long-term relationships with other family members, especially siblings". ${ }^{623}$

Irland hade visserligen en mycket säregen demografisk utveckling, präglad av en enorm emigration i spåren av 1850-talets hungersnöd, men situationen runt sekelskiftet 1900 uppvisar tydliga likheter med den svenska. Sverige hade tillsammans med Irland den högsta andelen ogifta i Europa och som framgått i denna bok var det även i Sverige vanligt med ogifta jordbrukare och samboende mellan syskon. ${ }^{624}$ Att många av de ogifta irländska syskonen fanns på stora jordbruk har också sin motsvarighet i svenska förhållanden. En premiss i Guinnanes argumentation är dock att gården och de materiella resurserna helt övertogs av en manlig arvinge och att medboende syskon i princip var egendomslösa. ${ }^{625}$ Det får till följd att hans resonemang har en tydlig könsbias - det var män som upphörde att gifta sig och ersatte hustrur med systrar, inte tvärtom. På denna punkt var de svenska syskonjordbruken mer komplicerade. Det fanns visserligen många syskonjordbruk där en bror ägde hela gården, men lika vanligt var att alla syskon var delägare. I grund och botten gäller dock samma principiella resonemang: genom att stanna på gården tillsammans behöll syskonen sin sociala och ekonomiska position, men till priset av att inte gifta sig. Syskonskap ersatte äktenskap.

Guinnanes resonemang har enligt min mening stor bärkraft på svenska förhållanden. Det har också effekten att det betraktar uteblivna äktenskap som resultatet av ett medvetet handlingsmönster, inte av en misslyckad strategi. Det ska emellertid inte tolkas som att alla syskonjordbruk uppstod på grund av att syskon på förhand valde bort äktenskap som alternativ. Familjen var en god organisatorisk grund för att hantera långsiktiga relationer och förändrade förutsättningar. Iréne Flygare framhåller syskonrelationernas elasticitet 
och förmåga att lindra effekterna av att vissa syskon gifte sig medan andra förblev ogifta. ${ }^{626}$ Hushåll med ogifta syskon var kanske inte följden av en ursprunglig strategi, men inte heller nödvändigtvis av en rakt igenom misslyckad strategi. En mer rimlig ståndpunkt är att betrakta strategier som föränderliga, som något som ständigt omtolkas i ljuset av erfarenheter, förutsättningar och framtidsutsikter. Sådana omtolkningar kunde ibland vara explicita. I intervjuerna återfanns exempelvis ett par syskon som i medelåldern enats om att som en gemensam strategi förbli ogifta för att bevara hushållets struktur. I andra fall - sannolikt de flesta - var sådana överenskommelser outtalade, men ändå styrande. Det krävdes, för att följa Guinnanes resonemang, att vissa förutsättningar var uppfyllda för att alternativet till äktenskap skulle bli tillräckligt attraktivt. Valet att förbli ogift kan således ha vuxit fram i samklang med den inre logiken i syskonhushållets sammansättning.

Till de fem delförklaringarna bör således läggas arvingarnas val att förbli ogifta. Resonemanget måste dock förankras i tid. Som tydligt framgått i denna bok var syskonhushållen en tidsbunden företeelse som inte uppstod förrän decennierna runt sekelskiftet 1900. Vad i dåtiden var det som skapade de samhälleliga förutsättningar som krävdes för att arvingar skulle avvika från tidigare handlingsmönster och förbli ogifta?

\section{Hemmansägarklassens undergrävande}

Sven Delblanc skildrar i romanerna Samuels bok och Samuels döttrar de skiftande öden som barnen till mäster Samuel Eriksson gick till mötes. En av sönerna, Benjamin, utackorderades 1910 som barn till den stora gården Berga, där Emmaus Elofsson huserade med sina sex syskon. Löftet var att han skulle få överta gården efter syskonens död. ${ }^{627}$ Den gård Benjamin kom till var således ett syskonjordbruk, vilket Delblanc tecknar i mörka färger:

Emmaus Elofsson och hans gruvliga syskon, Emil, Erik, Elsa, Elna och Egon, hade aldrig delat upp sin fädernegård inbördes, av pur 
snålhet och skräck för att sjunka i samhället. Om Emmaus som äldst i skaran hade fått överta gården, skulle de övriga tvingats gå ut som kroppsarbetare, statare, drängar, pigor, och det var en förnedring de fasade för, dessa storbondebarn på Berga. Så försmådde de friheten, kärleken och livet, satt kvar på gården som ungkarlar och gamjäntor, slet för brödfödan och hatade varandra som pesten. ${ }^{628}$

Syskonjordbruket på Berga i Delblancs berättelse kan tolkas som ett utslag av klassmedvetenhet. I en skrift som kom ut 1913, just efter att Emigrationsutredningens arbete avslutats, gav Gustav Sundbärg uttryck för en liknande tanke. "Det låter sig icke förneka", fastslog Sundbärg, "att 'böndernas andra storhetstid i Sverige' - såsom 1800-talet kan betecknas - numera starkt lider mot sitt slut." Han fortsatte: "det politiska herravälde, som bönderna under vid pass en mansålder utövade i vårt land, har icke efterlämnat något sympatiskt minne, till följd av en allt för långt driven 'klassmedvetenhet." ${ }^{629}$ Denna klassmedvetenhet hos 1800-talets bönder - eller hemmansägare, som de i kraft av sin starkare ekonomiska och sociala position började kalla sig - har blivit väl belyst i forskningen. ${ }^{630}$ Med start i det sena 1800 -talets jordbrukskris började emellertid grunden för deras position att vittra sönder. Några decennier in på 1900-talet var jordbruket en krisbransch, i behov av statligt stöd för att bönderna skulle nå samma levnadsstandard som den lönearbetande befolkningen. Sundbärgs bedömning var välgrundad. Hemmansägarepoken var på god väg att gå i graven.

Hemmansägarklassens utveckling har en parallell i en annan samhällsklass som fick problem i mötet med det moderna samhället: adeln. Ingvar Elmroth har i ett flertal studier undersökt den sociala rörligheten i olika sociala grupper före 1900-talet och särskilt adelns nyrekryteringar under 1600- och 1700-talen. ${ }^{631} \mathrm{I}$ ett sammanfattande arbete diskuterar han adelns tillbakagång och vad han benämner "utdöendet som en social process". I motsats till tidigare ansatser, som delvis hemfallit åt genetiska förklaringar till adelsätternas utdöende, betonar Elmroth den ekonomiska utvecklingen. För många inom adeln blev det nödvändigt att först säkra sin egen position, och så länge de inte nått tillräckligt långt 
i sin egen karriär var äktenskap och familjebildning inte aktuellt. Ätternas utdöende var, menar Elmroth, socialt betingat och en effekt av adelns svårigheter att upprätthålla sin maktställning. ${ }^{632}$ Många adelsmän såg sig "nödsakade att avstå från äktenskap eller på annat sätt begränsa sin familjebildning", vilket därmed ökade risken för ättens utslocknande. ${ }^{633}$ Men också för dem som gifte sig förändrades förutsättningarna. Brita Planck, som undersökt kärlek och äktenskap inom adeln mellan 1750 och 1900, pekar på hur betydelsen av börd förändrades över tid och tömdes på sitt politiska, juridiska och ekonomiska innehåll. Hon framhåller dock att bördens symboliska betydelse bestod och snarast ökade i takt med att dess övriga innehåll urholkades. ${ }^{634}$ På ett liknande sätt framhåller Angela Rundquist att "långa anor, nobla titlar och släktnätverket lyftes fram som allt överskuggande värden" och därigenom "kamouflerade tomrummet efter de facto förlorad politisk och ekonomisk makt".635

På samma sätt som adeln framträdde som mer traditionell när deras maktställning hotades, kan en liknande tendens skönjas när den starka hemmansägarekonomin gick mot sin upplösning decennierna runt sekelskiftet 1900. Familjerelationer lyftes fram som viktiga och det blev vanligare att gårdar överfördes i släkten. Så småningom manifesterades de långa anorna i släktgårdsdiplom. ${ }^{636}$ Tjänstefolk blev allt ovanligare och i det familjejordbruk som växte fram utfördes det mesta arbetet enbart av familjen. På punkt efter punkt isolerades bondefamiljen: hemmansägarna slog vakt om sig själva.

Det innebär inte att alla jordbrukare agerade på samma sätt. De flesta jordbruk överfördes fortfarande till en arvinge som också gifte sig. Många lyckades följa med sin tid, lösa successionsfrågan och investera för framtiden. I andra fall förstärktes den sociala medvetenheten. Att "gifta ner sig" kunde med denna logik vara ett socialt misslyckande som på alla vis borde undvikas. Detta sätter de många ogifta syskonen i ett annat ljus. I brist på lämpliga äktenskapspartner framstod alternativet att stanna i föräldrahemmet som godtagbart. De skapade därigenom ett nytt livsalternativ för bondbarn runt sekelskiftet 1900. På kort sikt fanns klara fördelar: 
syskonen kunde fortsatt ingå i en trygg gemenskap och åtnjuta social omsorg, de behöll sin sociala status och position och gårdens tillgång till arbetskraft säkrades. På längre sikt var osäkerheten desto större. Hemmansägarepoken gick mot sitt slut och den snabba omvandlingen av jordbruket innebar att tiden rann ifrån dem. De var fortsatt hemmansägare, men på övertid. 